\title{
Geology of volcanogenic massive sulfide deposit near Meli, northwestern Tigray, northern Ethiopia
}

\author{
Samuel Abraham, Bheemalingeswara Konka* and Solomon Gebreselassie \\ Department of Earth Science, College of Natural and Computational Sciences, P.O. Box 3066, \\ Mekelle University, Mekelle, Ethiopia (*kbheema2006@ gmail.com).
}

\begin{abstract}
Results of a preliminary study conducted on the volcanogenic massive sulfide (VMS) deposit near Meli/Rahwa, northern Ethiopia are presented in the paper. The study area forms part of Neoproterozoic basement of northern Ethiopia and southern part of the Arabian Nubian Shield (ANS). Selected surface rock samples of different lithologies and core samples from five boreholes were analyzed for petrography and geochemistry. The area consists of matabasalt, meta-andesite and meta-rhyolite, meta-volcaniclastics, phyllite and post-tectonic granite. The rocks have experienced low grade metamorphic conditions. Base metal mineralization, VMStype, is present and consists of pyrite, chalcopyrite, sphalerite and galena. Chloritization is the dominant alteration among others, and the ore body is associated with mafic to intermediate metavolcanic and metavolcaniclastic rocks and follows the same trend with the host rocks, striking north-south with subvertical dips. The mineralization is about $50-70 \mathrm{~m}$ long, $15-20 \mathrm{~m}$ thick and rich in copper and zinc (above 5\%) and Au as a byproduct which is in minable amount in the VMS-related gossan. The deposit is related to bimodal volcanic condition and is produced in an island arc tectonic setting.
\end{abstract}

Keywords: VMS, Base metals, Auriferous gossan, Meli/Rahwa, Tigray, Northern Ethiopia.

\section{INTRODUCTION}

Ethiopia is one of the northeastern African countries encouraging mineral exploration activities in a big way in recent times. This is visible since the last one decade or so. This trend has attracted both national and international mineral exploration companies to search for the metallic and non-metallic mineral resources in different parts of Ethiopia. Among others, gold and base metal sulfides are attracting the attention of many exploration companies like, National Mining Company, Ezana Mining Plc, Sheba Mineral Exploration Company, Donia Mineral Exploration Company, Harvest Mineral Exploration Company etc. Their efforts have resulted in delineation of many potential areas in Neoproterozoic basement for detailed exploration and drilling in different parts of the country. These efforts in Tigray region, northern Ethiopia, also have resulted in identifying many areas potential for gold and base metals. Gold in Ethiopia, dominantly occur as mesothermal variety within the basement rocks and is shear- hosted. At present it is being mined in southern Ethiopia at Legadembi and Sakaro (average grade of about 6ppm) (Tadesse, 2006, Tadesse, 2000). Base metal sulfide mineralisations on the other hand 
occur as either shear-controlled or volcanogenic massive sulfide (VMS) type. Among the shearhosted and VMS-related base metal deposits, the VMS- type are attracting more attention due to its poly-metallic content and massive character. Exploration activities are underway in many areas in the country particularly in Tigray region which include Meli, Terer, Terakempti, where drilling is being conducted to confirm the deposit and to evaluate and estimate the resource. These deposits are also attracting attention because they are gold-bearing (Bheemalingeswara and Atakilty, 2012; Ezana, 2008). On the other hand many vein-type shear-hosted occurrences for gold and base metals are reported from many areas in Tigray. For example, Negash (Bheemalingeswara and Nata, 2009), Abrha Astbhea, Hawzein (Bheemalingeswara et al., 2012) for base metals; and Workamba (Gebresilassie, 2009), May Habey (Mickiale, 2014), and Hawzein (Bheemalingeswara et al., 2015) for gold. Drilling is being conducted in many of these areas but main focus has been on gold occurrences.

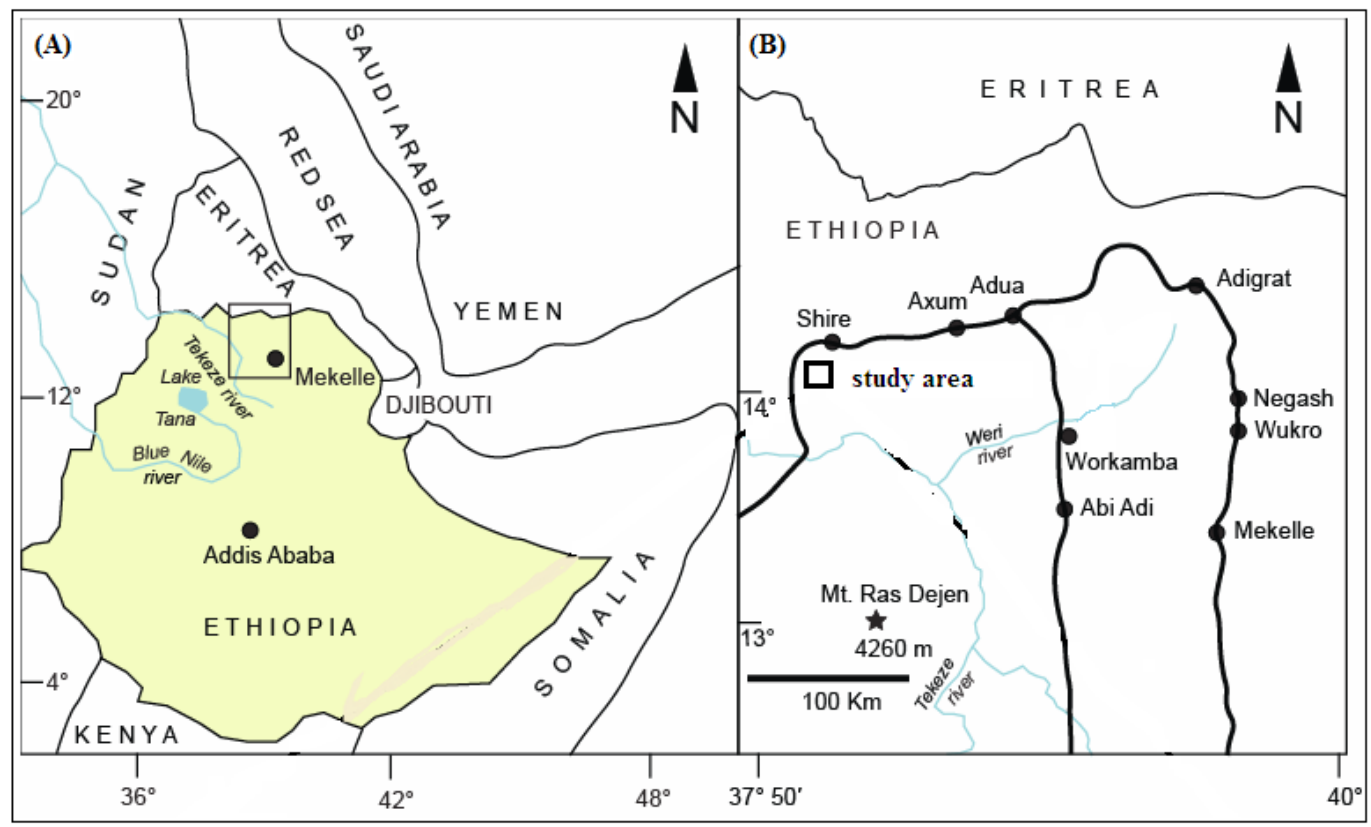

Figure 1. Location and accessibility map, A) Ethiopia, B) the study area.

In this regard, Ezana Mining Development Plc (EMD) (2008) is a pioneer exploration company which has identified and reported presence of auriferous poly-metallic VMS deposits near Rahwa/Meli in Adi Ekele belt and Terer in northwestern Tigray. These deposits are identified mainly based on the cap rock gossan developed on these sulfide deposits. Among these occurrences, the focus has been the Meli deposit which has about 30m thick gossan and is auriferous (having about 2t gold) (Bheemalingeswara and Atakilty, 2012). Diamond drilling has 
confirmed the presence of about 20-30m thick VMS deposit beneath the gossan (EMD, 2008). But at present the company is planning to mine the gossan for gold.

The present paper is focused on the Meli VMS occurrence and provides information on ore petrography, alteration patterns and metal content, host-rock geology, ore paragenesis mainly based on the core samples supplied by the Ezana Company.

The study area Meli/Rahwa is located in northwestern Tigray, about $371 \mathrm{~km}$ northwest of Mekelle, capital of Tigray state and $61 \mathrm{~km}$ southwest of Shire Indasillasie town $(1540000 \mathrm{~m}$ to $1545000 \mathrm{~m} \mathrm{~N}$ and $390000 \mathrm{~m}$ to $398000 \mathrm{~m} \mathrm{E}$ ) (Fig 1), found in the Adi-Arkay sheet (ND 37-10). It is accessible via an asphalted road from Mekelle to Shire Indasillasie and Endaba Gunan and by a gravel road to Meli.

\section{METHODOLOGY}

Among 30 boreholes drilled by EMD, five representative boreholes $\left(315^{0}\right.$ Azimuth, $55^{0}$ inclined towards east) were logged and sampled systematically. Samples were chosen from these five boreholes for petrographic study and geochemical analysis. Six surface rock samples were also chosen for petrography. The borehole logs are given in figure 2 and core sample location (depths) are given in tables 1 and 2. Thin and polished sections were prepared at Geological Survey of Ethiopia (GSE) central laboratory, Addis Ababa and petrographic study was done at Department of Earth Science, Mekelle University, using transmitted and reflected light microscopes. The rock powders of both core and surface rock samples about 100 grams were analyzed (using pressed pellet) for major and minor oxides using X-ray Fluorescence Spectrometer (XRF) at GSE, central laboratory, Addis Ababa. For trace elements, the powders were digested with $\mathrm{HClO}_{4}$ attack and the solutions were analyzed using Atomic Absorption Spectrophotometer at GSE laboratory. The data is given in tables 1 and 2.

\section{GEOLOGY OF THE AREA}

\subsection{Regional Geology}

The geology of the study area forms part of Arabian Nubian Shield (ANS), which is dominated by the juvenile Neoproterozoic crust, especially supracrustal greenschist facies and intrusive rocks (Avigad et al., 2007; Stern, 1994). These rocks were earlier divided into Lower, Middle and Upper Complexes by Kazmin $(1971,1975)$. Later they were divided into two major blocks 
(e.g. Ayalew et al., 1990; Teklay et al., 1998), (i) high grade gneissic and migmatitic terrain (consists of the Lower and Middle Complex rocks) correlated with the Mozambique Belt; (ii) low grade volcano-sedimentary terrain (comprising the rocks of the Upper Complex) correlated with the ANS. Accordingly, Ethiopian basement is composed of two major blocks, besides, pre-, syn- and post-tectonic granitoids (Asrat et al., 2001). Beyth (1972) further subdivided the basement rocks of the ANS in Tigray region into two groups based on stratigraphic relationships, (i) Tsaliet Group and (ii) Tambien Group. Tsaliet Group consists of arc-related metavolcanosedimentary rocks including metavolcaniclastic rocks, sericite-chlorite schist, slate, greywacke, impure marble, calcareous siltstone, well bedded, intermediate to acidic welded tuff, lappili tuff, and agglomerate (Beyth, 1972; Beyth et al., 2003; Tadesse et al., 1999; Alene et al., 2000). The Tambien Group (between 800 and 735Ma) on the other hand is mainly exposed in a series of synclinal inliers surrounded by the Tsaliet Group rocks, deposited in a shallow marine environment during a period of regional arc-magmatic lull (Avigad et al., 2007).

\subsection{Local Geology}

The study area consists of metavolcanics, metavolcaniclastics and metasediments of Neoproterozoic age and intruded by syn- and post-tectonic granitoids and has experienced polyphase deformations. The rocks belong to Tsaliet Group. Among the lithologies, mafic metavolcanic rock (MMV) covers the major part (Fig 2A) and is fine grained green colored rock. It shows poorly developed foliation trending SW-NE to E-W $\left(250^{\circ}-275^{\circ}\right)$ and dipping moderate to sub-vertical towards southeast and south. It is followed intermediate metavolcanic rock (IMV), also fine grained showing gray and pale greenish color (Fig 2A). It is massive and also strongly foliated trending from $260^{\circ}$ to $280^{\circ}$ and intruded by quartz veins and veinlets of different orientations. Felsic metavolcanic (FMV) rock next to IMV shows pale-gray color, non-foliated with fine grained texture and oriented SW-NE to E-W dipping sub-vertically towards south. It is traversed by quartz veins having different orientation and thickness ranging from $1 \mathrm{~cm}$ to $25 \mathrm{~cm}$. Intermediate metavolcaniclastic (IMVC) rock also shows fine groundmass with clasts of various sizes (few $\mathrm{mm}$ to $20 \mathrm{~cm}$ ) and shapes. It shows light to dark greenish gray color and moderately foliated. The rock is comprised of silicified, tuffaceous and epidotized rock fragments within the chlorite dominated groundmass. The clasts are irregular, angular, elliptical, sub-rounded in shape and show alignment due to stretching along down dip and the orientation of the rock ranges $245^{\circ}-270^{\circ}$ dipping $35^{\circ}-65^{\circ}$ due SE. Phyllite rock represents metasediment in the area and shows 
E-W trend. It is also fine grained, fissile and shows gray, black and pale red colors and is highly foliated with E-W orientation and is cut by aplitic dikes and quartz veins. At places bedding surfaces are also present.

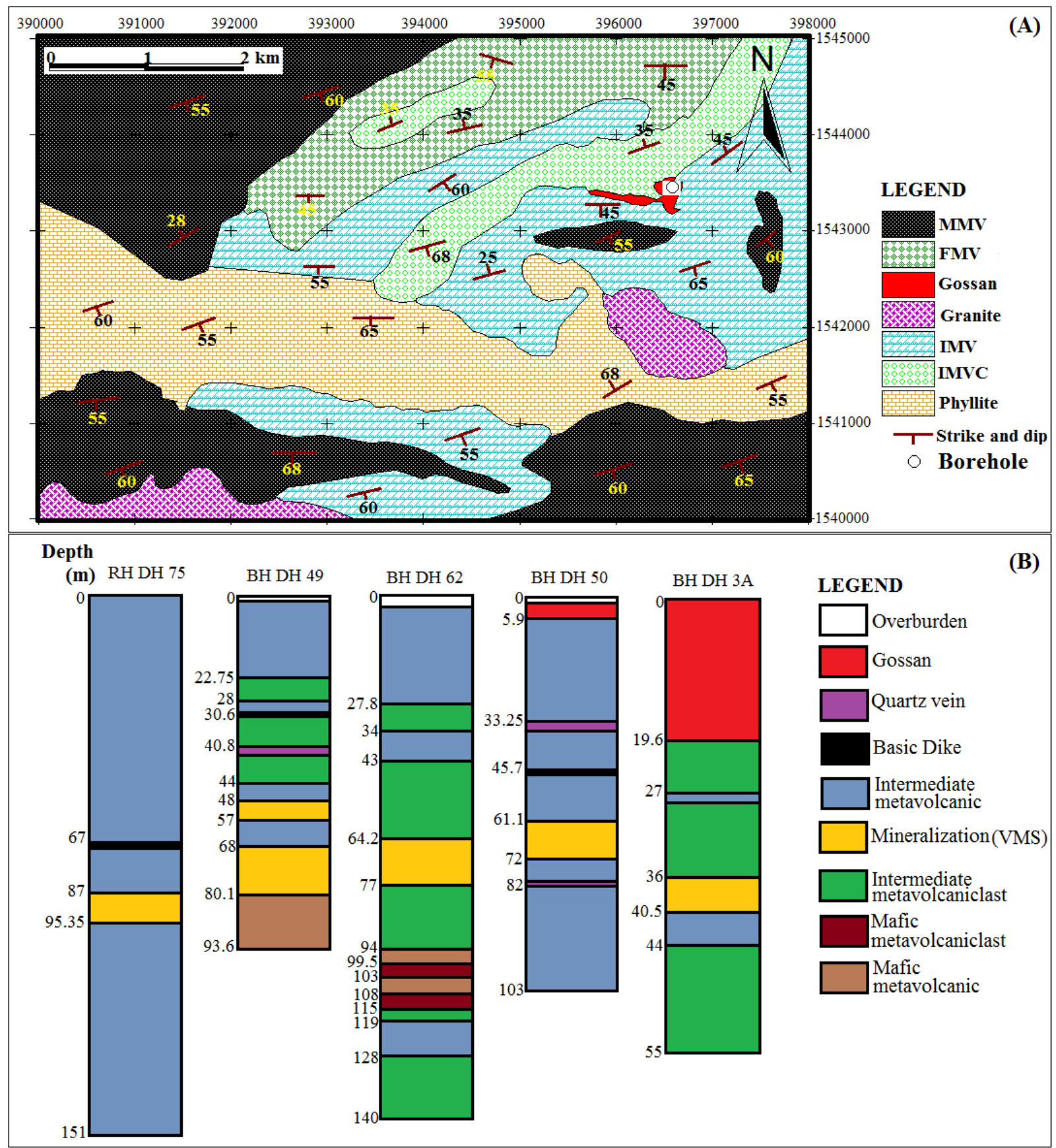

Figure 2. (A) Geological map of the study area (after Bheemalingeswara and Atakilt, 2012) and (B) drill core logs of five boreholes. 
Granite is medium- to coarse-grained, weakly weathered, light gray to pink color and considered post-tectonic based on the random arrangement of the minerals. It is composed mainly of quartz, K-feldspar with minor amounts of biotite and muscovite. Presence of dark colored, angular to sub-rounded, mafic xenoliths up to $20 \mathrm{~cm}$ is common. Apart from granite, swarms of aplitic dikes/sills ranging from $20 \mathrm{~cm}$ to $1 \mathrm{~m}$ in thickness are present in the area. They are fine to medium grained, light pink in color and mostly intruding phyllite and intermediate metavolcanic rocks. They are dominated by quartz and orthoclase and mostly follow the foliation trend SW to NE. At places theses are cut by the younger quartz veins. Quartz veins and veinlets up to $50 \mathrm{~cm}$ thick with NNW, NW and E-W orientations are extensively present and intrude all the lithologies. They show white and grey colors and at places are highly brecciated and few of them are goldbearing.

\subsection{Structures and Deformations}

Foliation is the most common structure with orientation, $260^{\circ}$ to $270^{\circ}$ with a dip of $25^{\circ}$ to $70^{\circ}$ due south east referring to D1 deformation. Two types of folds present are anticlinal folds in intermediate metavolcanic rocks with fold axis trending $260^{\circ}$ and plunging $55^{\circ} \mathrm{SE}$; and ptygmatic folds in quartz veins with a fold axis plunging $60^{\circ} \mathrm{SE}$. These are related to D2 deformation. Shear zones are the other structures with increasing density of foliation planes within the foliated rocks. Faults, both dextral (minor) and sinistral observed in northern and eastern parts of the area, with $315^{\circ}$ and $275^{\circ}$ respectively are present in phyllite and intermediate metavolcanics rock. It is related to D3 deformation. Joints are closely spaced, dense, mainly N-S trending, with vertical to sub-vertical dips and often filled by quartz veins. These narrow zones varying in thickness from few cms to $10 \mathrm{~m}$ exhibit highly fragmented rocks due to deformation and contain higher density of quartz veins. They show $260^{\circ}$ orientation and are related to D4 deformation. Apart from these, mineral lineation is also observed with $260-270^{\circ}$ orientation. Finally, the E-W trending and dipping $35^{\circ}$ to $65^{\circ}$ towards south bedding plane, a sedimentary structure, in phyllite.

\section{RESULTS}

\subsection{Petrography of the country rocks}

Among different lithologies present in the area, the rock types associated with mineralization are mainly mafic-intermediate metavolcanic rock (MMV) and intermediate metavolcaniclastics (IMVC). The MMV rock is dominated by chlorite and epidote and others include actinolite, 
quartz, plagioclase, calcite and opaques. It shows well developed schistosity and with tiny and discontinuous quartz veins (Fig 3). IMV shows well developed schistosity and consists of biotite, quartz, chlorite, epidote, orthoclase and plagioclase feldspar, calcite and opaque (Fig 3). Intermediate metavolcaniclastic rock (IMVC) is similar to IMV in mineralogy but differ in the presence of clasts and shows well developed schistosity. Phyllite is composed of muscovite and quartz and shows well developed foliation (Fig 3). Felsic metavolcanic rock (FMV) is dominated by xenoblastic quartz and followed by feldspar, muscovite, iron hydroxides and opaques. The rock shows well developed schistosity with quartz veins cutting across the fabric (not shown in figure 3 ).
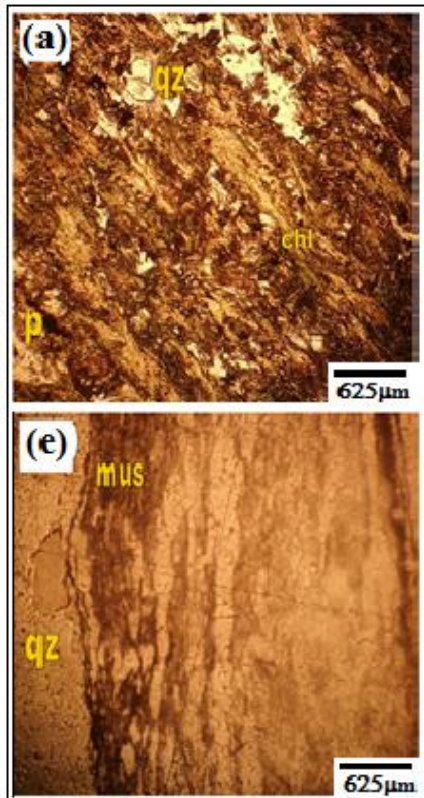
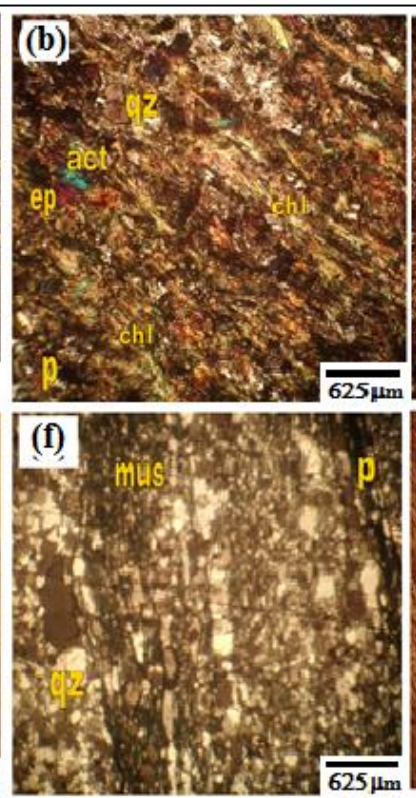
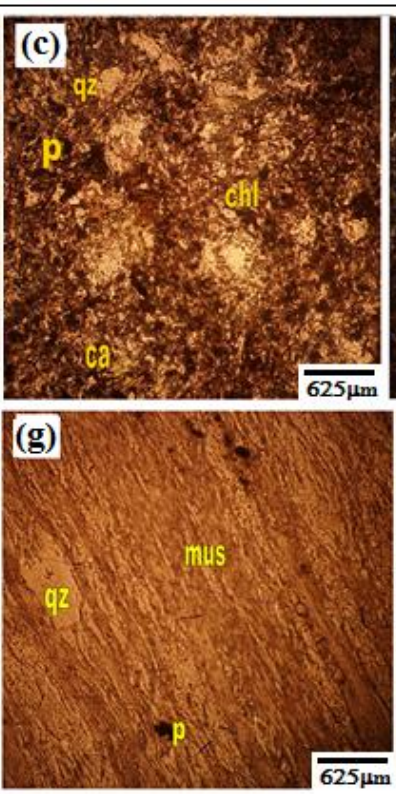
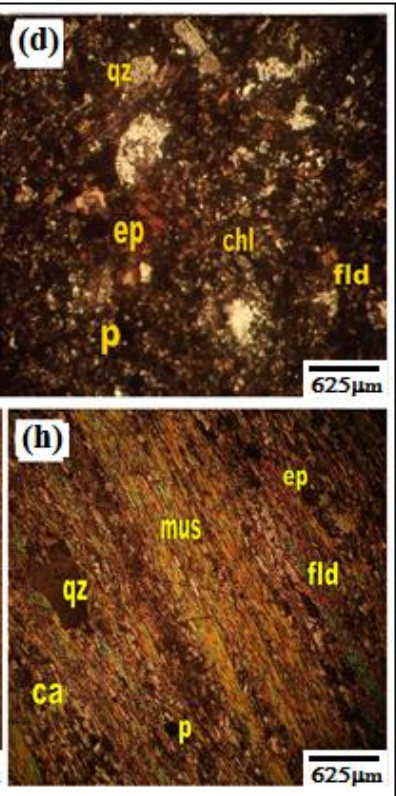

Figure 3. Microphotographs of (a) mafic metavolcanic rock (PPL) and (b) XPL; (c) intermediate metavolcanic rock (PPL) and (d) XPL; (e) metavolcaniclastic rock (PPL) and (f) XPL; and (g) phyllite (PPL) and (h) XPL [qz=quartz, chl=chlorite, act=actinolite, ca=calcite, $\mathrm{kfld}=\mathrm{k}$-feldspar, fld=feldspar, $\mathrm{bt}=$ biotite, mus=muscovite, $\mathrm{ep}=$ =pidote, $\mathrm{p}=$ opaque].

Alteration type is important criteria to understand the hydrothermal deposits e.g. load gold deposits, volcanogenic sulfide deposits, porphyry copper deposits etc. In the case of VMS, the pipe shows typically a sericite-chlorite-quartz-pyrite- rich margin and a quartz-chlorite-sulphiderich core (Galley et al., 1999).

Among different types of alterations, chloritization, ferrugenization, epidotization, sericitization, silicification and carbonization are found common in the present case. Chloritization, the 
dominant type, is observed in the rocks particularly in intermediate and mafic metavolcanic rocks where hydrothermal solutions interaction is more intense (Fig 3). A brecciated, possibly the vent, observed in the field, is also highly altered showing chloritization and sericitization. These alterations are assumed to be the result of the reaction of Fe-Si-Ca -rich hydrothermal fluid and the host rocks, and is common in the core of the pipe (Galley et al., 1999). Epidotization is observed in the massive to weakly foliated mafic metavolcanic and intermediate metavolcanic rock units while silicification is observed in the intermediate metavolcanic rocks in the central part of the area. Sericite alteration is common in the deformed and sulphidized felsic metavolcanic rock found in contact with gossan. Kaolinization, as indicated by the development of kaolin is also observed where feldspars are altered to clay. Calcite development as part of carbonitization showing xenoblastic texture is noted in many lithologies later to quartz veins. According to Galley et al. (1999), calcite is commonly found with $\mathrm{Zn}-\mathrm{Pb}-\mathrm{Cu}$ related VMS deposits associated with sericite-chlorite-quartz-pyrite alterations and is related low temperature hydrothermal fluids. Gossan development is another conspicuous feature in the area indicating alteration of sulfide minerals due to oxidation (Bheemalingeswara and Atakilty, 2012).

\subsection{Ore Petrography}

The petrographic investigation indicates presence of sulfide mineral assemblage, pyrite, chalcopyrite, sphalerite and galena in different proportions (Fig 4).

Pyrite is the most abundant sulfide. It has euhedral to irregular shape (idioblastic, xenoblastic and hypidioblastic textures), high polishing hardness, yellow color and as clusters with welldeveloped fractures. These fractures are filled by other sulfides particularly chalcopyrite and galena. Poikilioblastic texture is common where chalcopyrite, sphalerite and gangue minerals are found present within the pyrite crystals as inclusions (Fig 4).

Chalcopyrite follows next in the order and is the second dominant sulfide mineral present in the section. It is irregular, xenoblastic, and closely associated with pyrite particularly where pyrite occurs in clusters (Fig 4). It is dominantly associated with veinlets cutting pyrite and also as inclusions in pyrite. Interestingly, chalcopyrite is only mineral observed in the section others, bornite and covellite and chalcocite are not observed. 

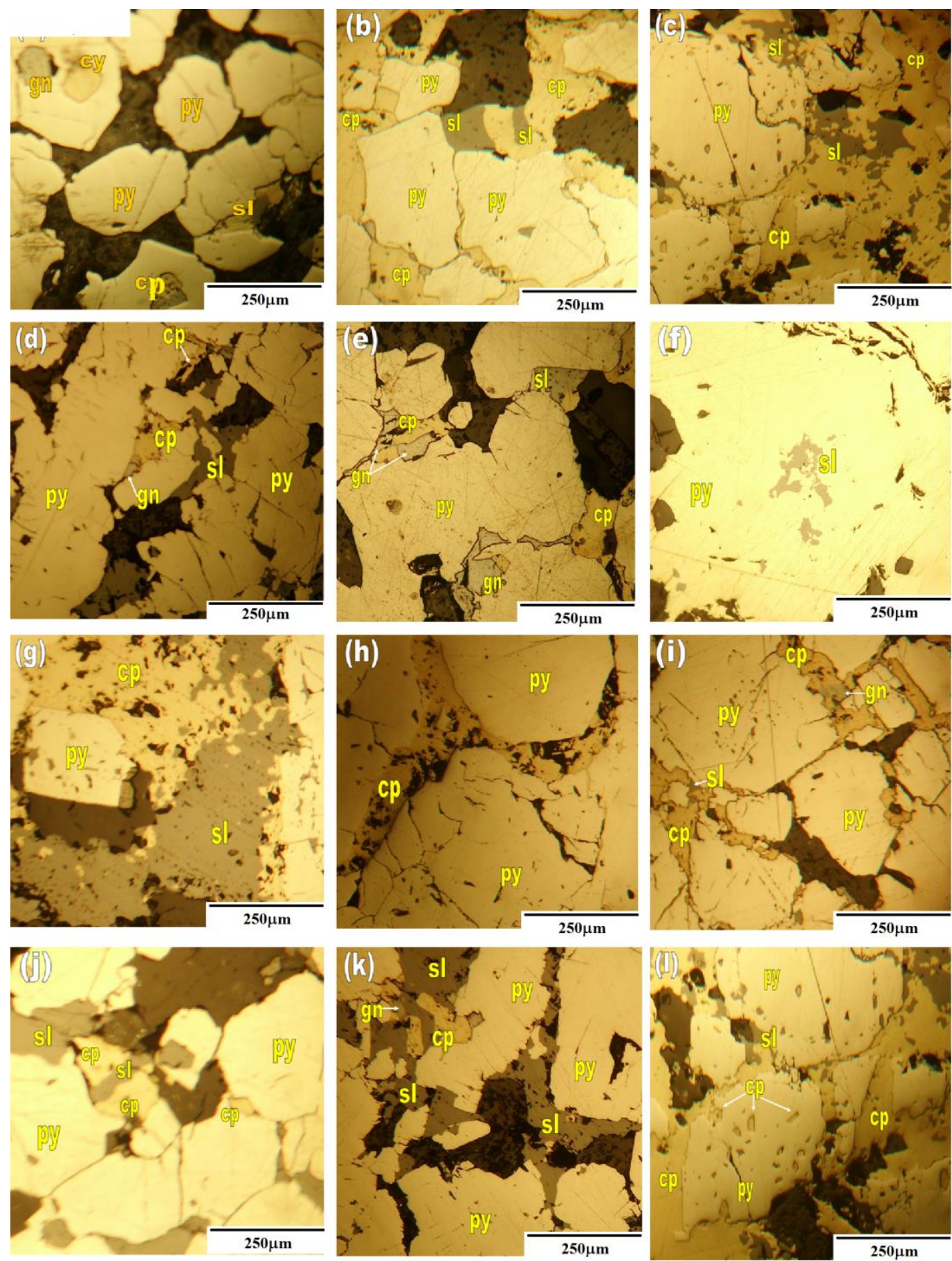

Figure 4. Reflected light photomicrographs showing relationships between sulphide minerals (PPL, 100X). (a) clusters of pyrite with chalcopyrite and galena which are formed later, (b) and (c) sphalerite inclusions in chalcopyrite, (d) sphalerite veinlets cutting pyrite, (e) galena inclusions in pyrite, (f) sphalerite inclusions in pyrite, (g) cluster of pyrite within chalcopyrite, (h) and (i) chalcopyrite veinlets cutting pyrite, (j) galena replacing chalcopyrite, $(\mathrm{k})$ sphalerite veinlets cutting pyrite and gangue minerals overgrowth in sphalerite, (1) chalcopyrite blebs in side pyrite [py=pyrite, $c p=$ chalcopyrite, $\mathrm{sl}=$ sphalerite and gn=galena]. 
Sphalerite is third in abundance among sulfides and found associated with pyrite, chalcopyrite and galena. It is subhedral to irregularly shaped crystal, massive and without fractures. It is being replaced by chalcopyrite and later pyrite. Overgrowth of sphalerite on the grains of chalcopyrite though not common indicates later part of remobilization during deformation stage. At places, it occurs as a single mineral in veinlets which cut pyrite and also present as inclusions within pyrite (Fig 4).

Galena is a minor phase present in the sections and is found as inclusion in pyrite as well as chalcopyrite apart from replacing chalcopyrite (Fig 4). Sphalerite and galena are seems to be developing together with pyrite but remained in the interstices of pyrite. However, galena is insignificant compared to sphalerite.

Deformation effects are indicated by the development of fractures in pyrite and partially in sphalerite. Remobilization of chalcopyrite and galena is resulted in filling these fractures. Pyrite being a continuous phase throughout the hydrothermal process compared to others shows variation in the beginning and end of the hydrothermal activity.

\subsection{Rock geochemistry}

Among different rock types present in the study area, only the rocks associated with mineralization are considered for geochemical analysis, which include mafic metavolcanics (MMV), intermediate metavolcanics (IMV) and intermediate metavolcaniclstics (IMVC). Major oxide (in wt $\%$ ) data is given in table 1 and trace elements (in ppm) data in table 2.

Mafic metavolcanic rocks have 45.39-53.6 wt $\% \mathrm{SiO}_{2}, 11.46-11.9$ wt $\% \mathrm{Al}_{2} \mathrm{O}_{3}, 7.6-9.96$ wt $\%$ $\mathrm{Fe}_{2} \mathrm{O}_{3}$, 9.34-9.7 wt $\% \mathrm{CaO}, 8.88-15.72$ wt $\% \mathrm{MgO}, 0.69-2.18$ wt $\% \mathrm{Na}_{2} \mathrm{O}, 1.7-2.31$ wt $\% \mathrm{~K}_{2} \mathrm{O}, 0.29-$ $0.81 \mathrm{wt} \% \mathrm{TiO}_{2}, 0.13-0.24 \mathrm{wt} \% \mathrm{MnO}$ and 0.13-0.64 wt $\% \mathrm{P}_{2} \mathrm{O}_{5}$. Similarly, intermediate metavolcanic rocks show variation from 60.65- $61.27 \mathrm{wt} \%$ for $\mathrm{SiO}_{2}, 13.83-14.36 \mathrm{wt} \% \mathrm{Al}_{2} \mathrm{O}_{3}$, 7.39-9.51 wt $\% \mathrm{Fe}_{2} \mathrm{O}_{3}, 2.44-2.89 \mathrm{wt} \% \mathrm{CaO}, 5.19-5.67 \mathrm{wt} \% \mathrm{MgO}, 3.44-4.04 \mathrm{wt} \% \mathrm{Na}_{2} \mathrm{O}, 1.63$ to $1.66 \mathrm{wt} \% \mathrm{~K}_{2} \mathrm{O}, 0.27-0.38 \mathrm{wt} \% \mathrm{TiO}_{2}, 0.04-0.06 \mathrm{wt} \% \mathrm{MnO}$ and 0.01-0.17 wt $\% \mathrm{P}_{2} \mathrm{O}_{5}$. In intermediate metavolcaniclasic rocks $\mathrm{SiO}_{2}$ values vary from 50.98 to $67.6 \mathrm{wt} \%, \mathrm{Al}_{2} \mathrm{O}_{3} 13.7$ to $15.95 \mathrm{wt} \%, \mathrm{Fe}_{2} \mathrm{O}_{3} 4.26$ to $10.04 \mathrm{wt} \%, \mathrm{CaO} 2.23$ to $4.48 \mathrm{wt} \%, \mathrm{MgO} 2.28$ to $7.80 \mathrm{wt} \%, \mathrm{Na}_{2} \mathrm{O}$ 2.17 to $5.91 \mathrm{wt} \%, \mathrm{~K}_{2} \mathrm{O} 1.25$ to $3.85 \mathrm{wt} \%, \mathrm{TiO}_{2} 0.29$ to $1.01 \mathrm{wt} \%, \mathrm{MnO} 0.08-0.1 \mathrm{wt} \%$, and $\mathrm{P}_{2} \mathrm{O}_{5}$ 0.12 to $0.73 \mathrm{wt} \%$. 
Table 1. Major, minor and trace elements geochemical analysis data for the rocks (surface samples with MR and core samples with $\mathrm{BH}$ ) of the study area.

\begin{tabular}{|c|c|c|c|c|c|c|c|}
\hline $\begin{array}{l}\text { Oxides/ } \\
\text { elements }\end{array}$ & $\begin{array}{l}\text { MR-45 } \\
\text { (MMV) }\end{array}$ & $\begin{array}{l}\text { BH- 21/49 } \\
\text { (MMV+ore) } \\
(80.6 m)\end{array}$ & $\begin{array}{l}\text { BH- 7/50 } \\
\text { (IMV+ ore) } \\
(55 m)\end{array}$ & $\begin{array}{l}\text { MR-3 } \\
\text { (IMV) }\end{array}$ & $\begin{array}{l}\text { BH- 8/62 } \\
\text { (IMVC+ore) } \\
(73.5 \mathrm{~m})\end{array}$ & $\begin{array}{l}\text { MR-08 } \\
\text { (IMVC) }\end{array}$ & $\begin{array}{c}\text { BH-1/62 } \\
\text { (IMVC) } \\
(59.6 m)\end{array}$ \\
\hline $\mathrm{SiO}_{2}$ & 53.6 & 45.39 & 60.65 & 61.27 & 50.98 & 67.6 & 57.07 \\
\hline $\mathrm{Al}_{2} \mathrm{O}_{3}$ & 11.9 & 11.46 & 13.83 & 14.36 & 15.95 & 13.7 & 15.54 \\
\hline $\mathrm{Fe}_{2} \mathrm{O}_{3}$ & 9.96 & 7.6 & 9.51 & 7.39 & 10.04 & 4.26 & 9.28 \\
\hline $\mathrm{CaO}$ & 9.70 & 9.34 & 2.44 & 2.89 & 3.78 & 2.23 & 4.48 \\
\hline $\mathrm{MgO}$ & 8.88 & 15.72 & 5.67 & 5.19 & 7.80 & 2.28 & 7.09 \\
\hline $\mathrm{Na}_{2} \mathrm{O}$ & 2.18 & 0.69 & 3.44 & 4.04 & 3.54 & 5.91 & 2.17 \\
\hline $\mathrm{K}_{2} \mathrm{O}$ & 0.17 & 2.31 & 1.66 & 1.63 & 3.85 & 1.25 & 1.96 \\
\hline $\mathrm{TiO}_{2}$ & 0.29 & 0.81 & 0.38 & 0.27 & 1.01 & 0.29 & 0.43 \\
\hline $\mathrm{MnO}$ & 0.24 & 0.13 & 0.06 & 0.04 & 0.10 & 0.08 & 0.08 \\
\hline $\mathrm{P}_{2} \mathrm{O}_{5}$ & 0.13 & 0.64 & 0.17 & 0.01 & 0.73 & 0.12 & 0.15 \\
\hline
\end{tabular}

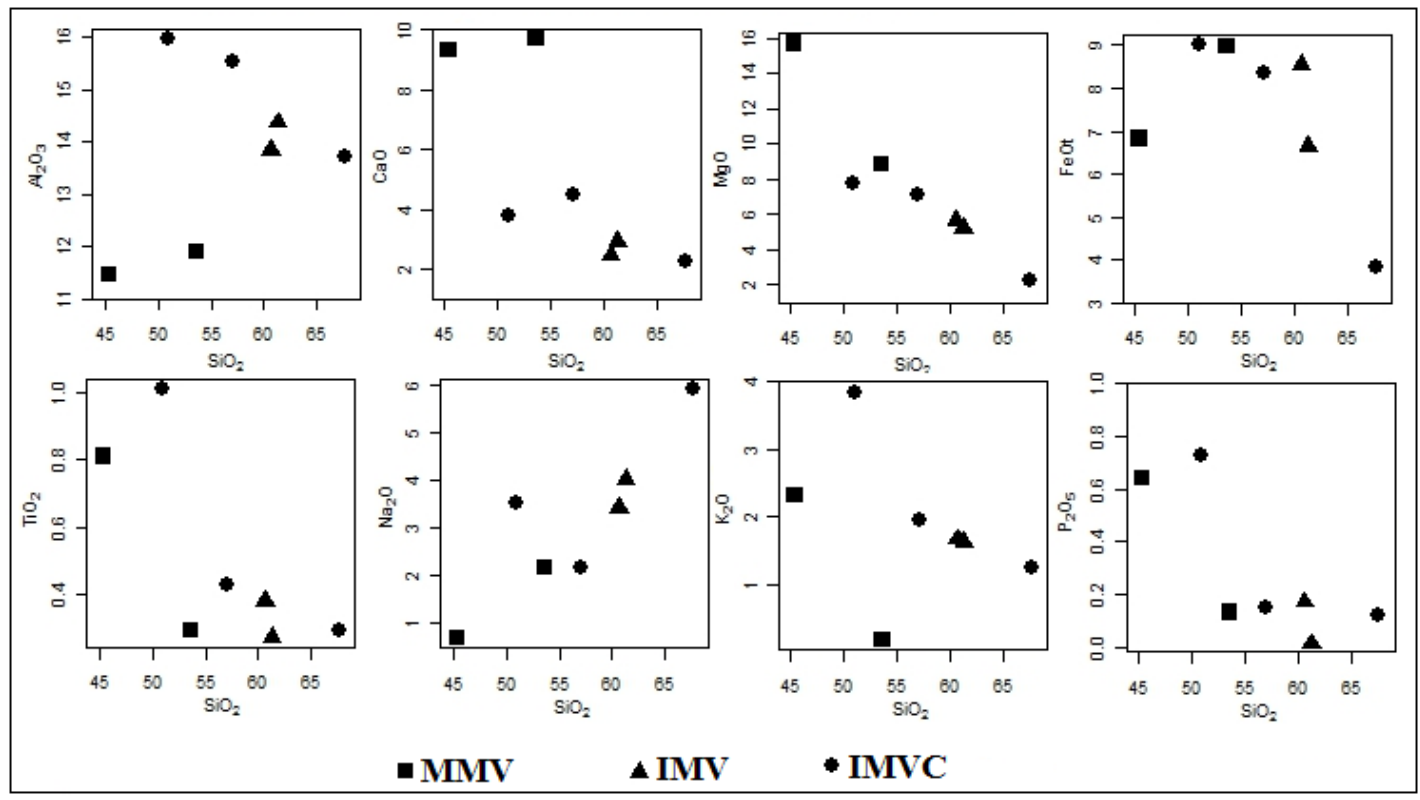

Figure 5. Relation of major oxides with $\mathrm{SiO}_{2}$ in MMV, IMV and IMVC rocks.

All major oxides $\mathrm{Al}_{2} \mathrm{O}_{3}, \mathrm{MgO}, \mathrm{TiO}_{2}, \mathrm{CaO}, \mathrm{K}_{2} \mathrm{O}, \mathrm{Fe}_{2} \mathrm{O}_{3}$ and $\mathrm{MnO}$ are showing normal differentiation trends either increase or decrease systematically in relation to $\mathrm{SiO}_{2}$ (Fig 5). Both MMV and IMV clearly show increase in $\mathrm{Al}_{2} \mathrm{O}_{3}$ with increasing $\mathrm{SiO}_{2}$ whereas IMVC do not follow the same trend (Fig 5). It may be due to the presence of clasts. Decrease in the values of $\mathrm{CaO}, \mathrm{MgO}, \mathrm{Fe}_{2} \mathrm{O}_{3}$ and $\mathrm{TiO}_{2}$ with increasing $\mathrm{SiO}_{2}$ suggest the normal magma crystallization trend and the same magma source (Thornton and Tuttle, 1960). Both $\mathrm{K}_{2} \mathrm{O}$ and $\mathrm{Na}_{2} \mathrm{O}$ are generally 
expected to increase with $\mathrm{SiO}_{2}$ but $\mathrm{Na}_{2} \mathrm{O}$, though follow the trend, $\mathrm{K}_{2} \mathrm{O}$ show reverse trend (Fig 5). Lower values for $\mathrm{K}_{2} \mathrm{O}$ seem to suggest their mobility during alteration and metamorphism (Alene et al., 2000). $\mathrm{P}_{2} \mathrm{O}_{5}$ versus $\mathrm{SiO}_{2}$ do not suggest any significant relation. According to Peccerillo and Taylor (1976) $\mathrm{SiO}_{2}$ vs $\mathrm{K}_{2} \mathrm{O}$ plot, the volcanic rocks MMV, IMV and IMVC with which the mineralization is associated, indicate that MMV are ranging from tholetiic to shoshonite composition (Fig 6a), IMV are related to calc-alkaline and IMVC range from calcalkaline to shoshonite composition (Fig 6a). The same when plotted in $\mathrm{SiO}_{2} \mathrm{vs}^{\mathrm{Na}} \mathrm{O}_{2} \mathrm{O}+\mathrm{K}_{2} \mathrm{O}$ plot, all the samples except one are falling in shoshonite field (Fig 6b). In figure 9 a and b, it is clear that $\mathrm{K}_{2} \mathrm{O}$ values do not show any increment with increasing $\mathrm{SiO}_{2}$, but when combined with $\mathrm{Na}_{2} \mathrm{O}$ the trend becomes clear. So, the $\mathrm{K}_{2} \mathrm{O}$ values are clearly reduced due to their mobilization during metamorphism compared to $\mathrm{Na}_{2} \mathrm{O}$. The trends thus suggest the same magma source for the volcanic rocks.
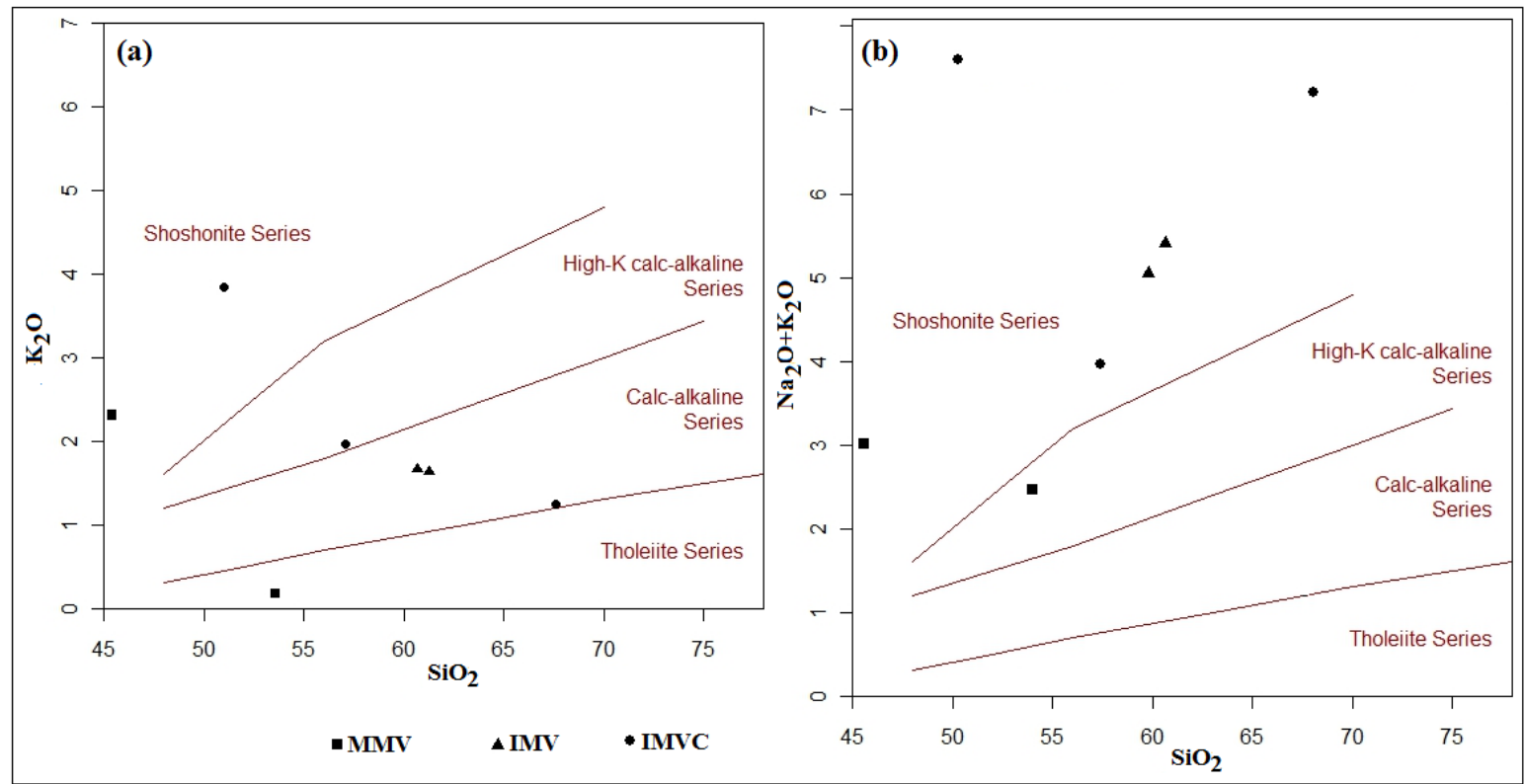

Figure 6. a) $\mathrm{SiO}_{2} \mathrm{vs} \mathrm{K}_{2} \mathrm{O}$ (, b) $\mathrm{SiO}_{2} \mathrm{vs} \mathrm{Na}_{2} \mathrm{O}+\mathrm{K}_{2} \mathrm{O}$ plot for MMV, IMV and IMVC rocks.

The $\mathrm{SiO}_{2}$ and other major oxides of metavolcanic rocks compare well with the same from Adi Nebrid block, where $\mathrm{SiO}_{2}$ values range from 47.02 to 72 wt \% (Tadesse et al., 1999). The same from Negash, Abraha Weatsbeha-Adi Desta and Hawzen which have $\mathrm{SiO}_{2}, \mathrm{Al}_{2} \mathrm{O}_{3}$ and $\mathrm{FeO}_{3}$ values ranging from 0.71 to 15.9 , from 2.52 to 9.3 and from 0.73 to $6.38 \mathrm{wt} \%$ respectively (Bheemalingeswara and Nata, 2009; Bheemalingeswara et al., 2012; Alene et al., 2000). 


\subsection{Ore Geochemistry}

Samples from the mineralized core show significantly higher values for copper and zinc. Copper content ranges from 8360 to 59280 ppm, zinc from 1700 to 52880 and lead from 6.4 to 1652 ppm (Table 2). The data is comparable with the petrography where the dominant mineral observed is chalcopyrite. Chalcopyrite is followed by sphalerite in abundance and is well reflected in the geochemical data. Among base metal sulfides, galena is present in negligible quantity and is well reflected in the low values for lead in geochemical data. The mean values for base metals also reflect the same view. For copper, the mean value is 29668 ppm, while for zinc it is 12505 and for lead $556 \mathrm{ppm}$. Average value for cobalt and nickel is 24.5 and $4.57 \mathrm{ppm}$ respectively. Interestingly, the base metal values are similar with the primary massive sulfide deposit of Bisha VMS deposit, western Nakfa terrane Eritrea (Bheemalingeswara and Atakilty, 2012). Similarly, the major oxide values are comparable with the metavolcanics of the Adi Nebrid Block (Tadesse et al., 1999).

Table 2. Geochemical data (in ppm) for base metals in core samples from mineralized zone.

\begin{tabular}{|c|c|c|c|c|c|c|c|}
\hline Element & $\begin{array}{l}\text { BH 03/62 } \\
\text { (ore with } \\
\text { IMVC, } \\
63.4 m \text { ) }\end{array}$ & $\begin{array}{l}\text { BH 05/62 } \\
\text { (ore with } \\
\text { quartz vein, } \\
63.4 m \text { ) }\end{array}$ & $\begin{array}{l}\text { BH } \\
09 / 62 \\
(\text { ore, } \\
77.6 m)\end{array}$ & $\begin{array}{l}\text { BH } \\
18 / 49 \\
(\text { ore, } \\
69.5 m)\end{array}$ & $\begin{array}{l}\text { BH } \\
11 / 50 \\
\text { (ore, } \\
70.5 m)\end{array}$ & $\begin{array}{l}\text { BH } \\
04 / 03 \\
\text { (ore, } \\
35.5 m)\end{array}$ & $\begin{array}{l}\text { MC 06 } \\
\text { (ore, } \\
92 m)\end{array}$ \\
\hline $\mathrm{Cu}$ & 50780 & 18600 & 12120 & 59280 & 8360 & 26060 & 32480 \\
\hline $\mathrm{Zn}$ & 1700 & 7320 & 14140 & 4020 & 52880 & 2620 & 4860 \\
\hline $\mathrm{Pb}$ & 6.4 & 25.6 & 1652 & 112 & 1388 & 17 & 688 \\
\hline
\end{tabular}

\section{DISCUSSION}

\subsection{Paragenesis and Paragenetic Sequence}

Field observations together with petrography suggest presence of well-developed, about $30 \mathrm{~m}$ thick auriferous gossan represented by limonite, goethite and hematite overlying the massive sulfide mineralization. It displays variegated reddish brown, dark red, yellowish and light reddish colors (Bheemalingeswara and Atakilt, 2012). Borehole logs suggest that the base metal sulfide mineralization exists subsurface with variable thickness, maximum about $15 \mathrm{~m}$. The ore body is massive and lensoidal in nature and 2-3 lenses are present. However, except one, others are thin and negligible. The ore body exists between the contact between either IMV and MMV or IMV and IMVC or between flows of IMV or IMVC. The pipe is not clearly visible but a channel with 
breccia is in the southern part of the gossan. Based on the association of ore body and host rocks, it is clear that the ore body is following the trend of the host rocks and the contact is quite sharp and alteration is quite conspicuous in the rocks along the contact. Variation in the composition of the volcanics from felsic to intermediate to mafic indicates bimodal volcanism. Association of ore body with intermediate to mafic volcanics supports copper-rich followed by zinc-rich sulfides compared to lead sulfide.

Time

\begin{tabular}{|l|l|}
\hline Sulfides & Mineralization - Deformation - \\
\hline Pyrite & - \\
Galena & \\
Sphalerite & \\
Chalcopyrite &
\end{tabular}

Figure 7. Paragengetic sequence suggested for the VMS mineralization.

It is a key to understand the genesis of mineralization on the basis of the sequence of events in terms of hydrothermal activity and related alteration patterns, sequence of minerals both gangue and ore minerals and sequence of tectonic activities etc. According to Craig and Vaughan (1994), the veinlet or other structure that crosscuts another is younger than that which cuts across, except when the older phase has been replaced or when both features result from metamorphic remobilization. Among the veins, quartz veins are related to many generations whereas calcite veins represent the last phase of hydrothermal activity. Quartz veins belong to different generations and some of them are gold-bearing up to $10-15 \mathrm{ppm}$, as noted in gossan (Bheemalingeswara and Atakilty, 2012). Calcite veins, sub-ordinate to quartz veins remain the youngest. Based on the characteristics of the ore body it is related to volcanogenic massive sulfide deposit with $\mathrm{Cu}$ and $\mathrm{Zn}$ metals and gold as a byproduct (Bheemalingeswara and Atakilty, 2012). Regarding sulfide minerals, galena, chalcopyrite, sphalerite and pyrite, some of them represent two generations. The first generation is related to the mineralization process and formed in the sequence of galena/pyrite $\rightarrow$ sphalerite $\rightarrow$ chalcopyrite $\rightarrow$ pyrite. Replacement is the main form by which the older are replaced by the younger. It is evidenced by the presence of the remnants of the older minerals in the form of inclusions, filling interstices of the grains and 
their concave and convex faces. So, the first generation ore minerals indicate replacement textures. The second generation ore minerals show fracture filling textures and are related to metamorphism, deformation, orogeny and intrusive pluton. Among the sulfides, the fractures are well developed in pyrite because it is hard and without cleavage compared to others. The softer minerals are found filling the fracture in pyrite and others. The sequence is pyrite $\rightarrow$ sphalerite $\rightarrow$ chalcopyrite $\rightarrow$ galena (Fig 7). The paragenetic sequence is given in figure 7 .

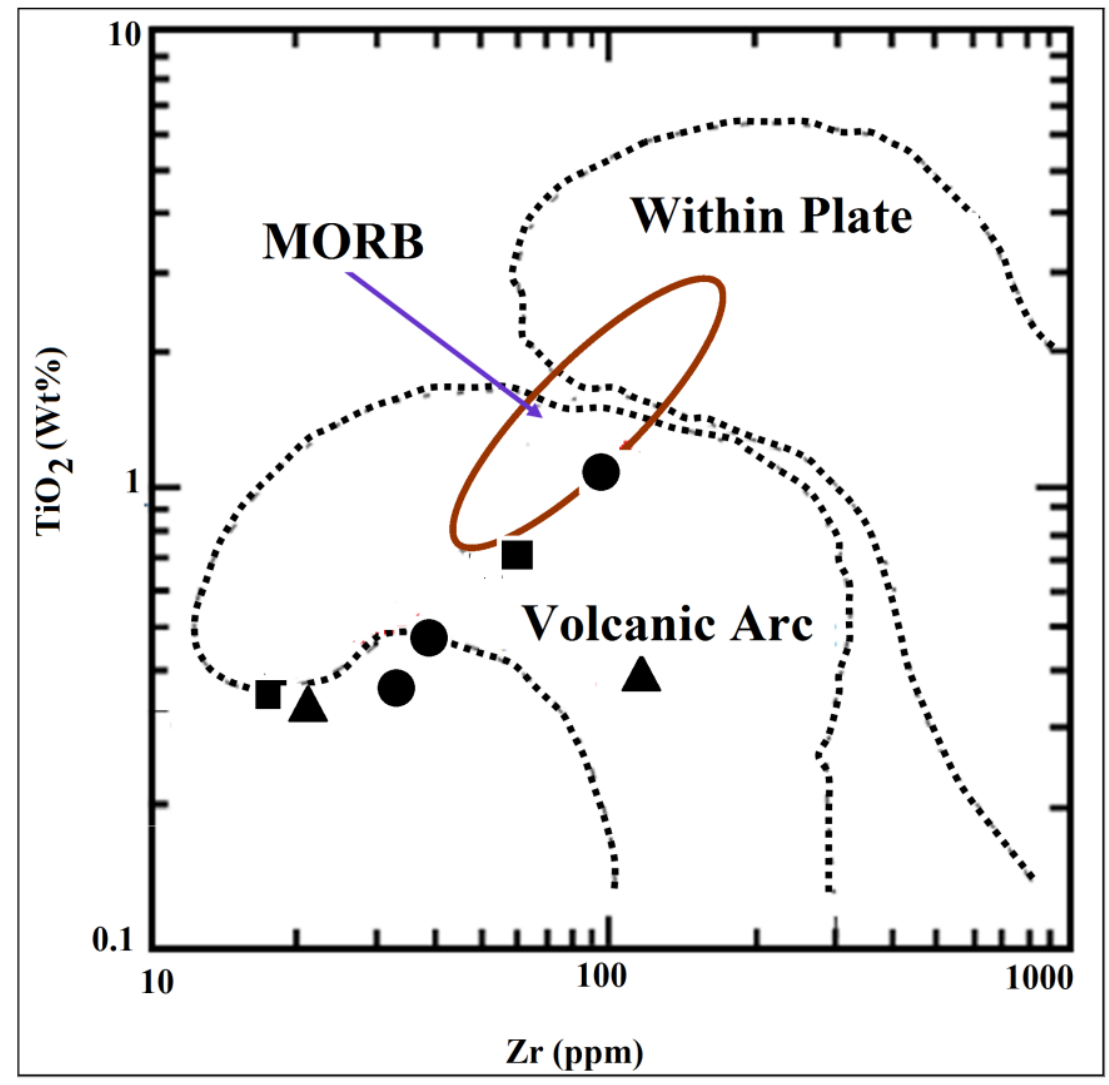

Figure 8. Tectonic discrimination diagram for the rocks of the study area. $\mathrm{TiO}_{2}$ versus $\mathrm{Zr}$ (Pearce, 1980). MORB= Mid Oceanic Ridge.

\subsection{Tectonic setting and Ore Genesis}

VMS is a type of metal sulfide ore deposit of mainly $\mathrm{Cu}-\mathrm{Zn}-\mathrm{Pb}$ and are associated with and created by volcanic associated hydrothermal events in sub-marine environments. They are predominantly layered accumulation of sulfide minerals that precipitate from hydrothermal fluids on or below the sea floor in a wide range of ancient and modern geological settings (Barrie et al., 2007). They are classified using different criteria like metal content, type locality and most widely used host lithostratigraphy and geodynamic setting. Under lithostratigraphic classification 
the deposits are classified into five groups, 1. mafic (Cyprus type), 2. mafic-siliciclastic (or politic-mafic, Besshi type), 3. bimodal- mafic (Noranda type), 4. bimodal- felsic (Kuroko type) and 5. felsic-siliciclastic (or bimodal- siliciclastic, Bathurst type) (Piercey, 2011 and references therein). Different genetic models are also being forwarded, such as magmatic, strata- aquifer, and convective model (Lydon, 1988). Further refinement in the understanding of the deposits is also suggested based on the alteration types and zones, and enrichment and depletion of the elements in each zone along the margins and core of the pipe. For example in Noranda type, the alteration zones will be immediately below the $\mathrm{Cu}$ - $\mathrm{Zn}$ deposit whereas the alteration zones will be adjacent in the case of Mattabi type $\mathrm{Zn}-\mathrm{Cu}-\mathrm{Pb}$ deposit and the zones will be in association with Kuroko type $\mathrm{Zn}-\mathrm{Pb}-\mathrm{Cu}$ deposit (Gibson and Kerr, 1993). Based on these, the deposit at Meli/Rahwa is inferred that it is produced by volcanic- associated hydrothermal events where the metals are leached from the country rocks, precipitated in the form of sulfide minerals and produced a lensoidal massive sulfide deposit prior to the metamorphic event. Its association with MMV, IMV and IMVC correlate well with the expected metal content i.e. $\mathrm{Cu}-\mathrm{Zn}$. The lithological variations suggests bimodal type deposit. The metal content and the host lithologies suggests its similarities with Noranda type VMS. The nature of the deposit is thus typically related to VMS not to shear-hosted orogenic type. Gold occurs as bi-product, though not evident in the petrographic observation, is clearly noted in the gossan (Bheemalingeswara and Atakilty, 2012). Like many VMS deposits, globally characterized by a relatively low gold grade $(<2 \mathrm{~g} / \mathrm{t})$ (Mercier-Langevin et al., 2011), Meli deposit is also characterized by low content of gold based on the geochemical and petrographic data. However, higher content of gold in gossan is due to residual enrichment.

Based on the discrimination diagram drawn between $\mathrm{TiO}_{2}$ (wt \%) and $\mathrm{Zr}$ (ppm) for MMV, IMV and IMVC rocks (Pearce, 1980), it is suggested that the rocks are produced in an island arc tectonic setting (Fig 12). It is consistent with the metavolcanic rocks of Tsaliet Group (related to island arc magmatism) reported from different parts of Tigray, e.g. Adi Nebrid, Negash, Abraha Weatsbeha-Adi Desta and Hawzein (Alene et al., 2000; Tadesse et al., 1999) and equivalents in Eritrea, dated $854 \pm 3 \mathrm{Ma}$ (Teklay et al., 1997) .

Many sulfide deposits are reported from ANS (about 60), out of which majority of them are VMS deposits, with intermediate to felsic volcanics as host rocks. The study area since forms part of the southern part of ANS, Meli deposit forms part of the same (Barrie et al., 2007). 
Among others, Bisha VMS deposit in western Nakfa terrane, Eritrea which is under exploitation has similar regional geological setting and is comparable. The geology of Bisha is also covered by low to medium grade Neoproterozoic metavolcanic rocks varying in composition from mafic to felsic and related to bimodal igneous suite with tholeiitic to transitional calc-alkaline affinities (Barrie et al., 2007). Similar to Meli, Bisha also produced about 30m thick auriferous gossan with dominant chloritic alteration compared to sericitization, kaolinization and silicification (Barrie et al., 2007). Both the deposits are rich in $\mathrm{Cu}$ and $\mathrm{Zn}$ sulfides are dominated by pyrite, chalcopyrite, sphalerite and galena mineral assemblage at Meli and pyrite, sphalerite, chalcopyrite and minor to trace galena, pyrrhotite, tetrahedrite, tennantite, arsenopyrite, barite and gangue in Bisha VMS (Barrie et al., 2007). The impact of granitic pluton on VMS is not clear. Different generations of quartz veins present in gossan and mineralization could be one contribution. Though, some of the quartz veins are gold bearing (Bheemalingeswara and Atakilt, 2012), the kind of modifications in VMS, due to pluton is still uncertain.

\section{CONCLUSION}

Meli area consists of Neoproterozoic basement rocks, matabasalt, metaandesite and metarhyolite metavolcaniclastic and phyllite and intruded by post-tectonic granite. Mineral assemblage and well development of schistosity suggest that the rocks have experienced low grade metamorphic conditions. Field observation and petrographic examination of the rocks reveal the development of different types of alterations like ferrugenization, chloritization, epidotization, silicification, sericitization related to hydrothermal fluid and rock interaction. The ore body, about 20-30 m thick and $100 \mathrm{~m}$ long, is massive, lensoidal, fine to medium grained. Ore minerals present are pyrite, chalcopyrite, sphalerite and galena and secondary minerals like chalcocite/covellite and goethite/limonite. Petrographical and geochemical data indicate that the mineralization is dominated by chalcopyrite and sphalerite minerals; and rich in $\mathrm{Cu}$ and $\mathrm{Zn}$. The ore body is present at the contact between metavolcanic rocks of mafic and intermediate compositions. Gossan developed on the ore body being auriferous, makes this deposit economically viable. The mineralization is also metamorphosed and based on the nature, host rock composition it is categorized as $\mathrm{Cu}-\mathrm{Zn}(+\mathrm{Au})$-rich, bimodal VMS mineralization and produced in an island arc tectonic setting. . 


\section{ACKNOWLEDGEMENTS}

This paper forms part of research project titled "A preliminary geological and geochemical investigation for gold and base metal mineralization west of Hawzein, Tigray, northern Ethiopia (CNCS/RB/39/2013)" funded by the recurrent budget of College of Natural and Computational Sciences, Mekelle University. The financial support is duly acknowledged. This paper also forms part of the M.Sc thesis of Mr. Samuel Abraham.

\section{REFERENCE}

Alene, M., Ruffini, R \& Sacchi, R. 2000. Geochemistry and geotectonic setting of Neoproterozoic rocks from northern Ethiopia (Arabian-Nubian Shield). Gondwana Research, 3: 333-347.

Asrat, A., Barbey, P \& Gleizes, G. 2001. The Precambrian Geology of Ethiopia: A review. Africa Geoscience Review, 8: 271-288.

Avigad, D., Stern, R.J., Beyth, M., Miller, N \& McWilliams, M.O. 2007. Detrital zircon U-Pb geochronology of Cryogenian diamictites and Lower Paleozoic sandstone in Ethiopia (Tigray): Age constraints on Neoproterozoic glaciation and crustal evolution of the southern Arabian-Nubian Shield. Precambrian Research, 154: 88-106.

Ayalew, T., Bell, K., Moore, J. M \& Parkish, R. R. 1990. U-Pb and Pb-Sr geochemistry of the western Ethiopian Shield. Geological Society of America Bulletin, 102:1309-1316.

Barrie, C. T., Nielson, F. W \& Claude, H. 2007. The Bisha, volcanic-associated massive sulfide deposit, Western Nakfa terrane, Eritrea. Society of Economic Geologists, Inc. Economic Geology, 120:717-738.

Beyth, M. 1972. The geology of central-western Tigray. Ph.D Thesis, Rheinche Friedrich Wilhems Universitate, Bonn, Germany, 159p (unpubl.).

Beyth, M., Avigad, D., Wetzel, H. U., Mattews, A \& Berhe, S. 2003. Crustal Exhumation and indications for snowball Earth in the East African Orogen: north Ethiopia and east Eritrea. Precambrian Research, 123: 187-201.

Bheemalingeswara, K \& Nata Tadesse. 2009. Petrographic and geochemical study of low grade metamorphites around Negash with a reference to base metal mineralization and ground water quality, Tigray, northern Ethiopia. Momona Ethiopian Journal of Science, 1(2): 106-132. 
Bheemalingeswara, K., Solomon Gebresilassie \& Kassa Amare. 2012. Shear zone-hosted base metal mineralization near Abraha Weatsbeha-Adi Desta and Hawzen, Tigray Region, Northern Ethiopia. Momona Ethiopian Journal of Science, 4(1): 3-28.

Bheemalingeswara, K \& Atakilty Araya, 2012. Rahwa auriferous gossan, northern Ethiopia: A strong indicator of subsurface massive sulfide mineralization. International Journal of Earth Sciences and Engineering, 5(3): 402-408.

Bheemalingeswara, K., Miruts, H \& Zelalem, H. K. 2015. A preliminary geological and geochemical investigation for gold and base metal mineralization west of Hawzein, Tigray, northern Ethiopia. Research Project Report, College of Natural and Computational Sciences, Mekelle University, Mekelle, Ethiopia, 33p (unpubl.).

Craig, J.R \& Vaughan, D.J. 1994. Ore microscopy and Ore petrography. A Willey Interscience Publication, John Wiley and Sons, 405p.

Ezana Mining Development PLC (EMD). 2008. Geological and Geochemical Report of Rahwa. Report, Mekelle, Ethiopia (unpubl.).

Galley, A.G \& Koski, R.A. 1999, Setting and characteristics of ophiolite-hosted volcanogenic massive sulfide deposits. In: C. T. Barrie and M.D. Hannington (eds.), VolcanicAssociated Massive Sulfide Deposits: Processes and Examples in Modern and Ancient Settings. Reviews in Economic Geology, 8: 215-236.

Gebreselassie, S. 2009. Nature and characteristics of metasedimentary rock hosted gold and base metal mineralization in the Workamba area, central Tigray, northern Ethiopia. Ph.D Thesis, Ludwig-Maximilians University, Munich, Germany, 134p.

Kazmin, V. 1971. Precambrian of Ethiopia. Nature, 230:176-177.

Kazmin, V. 1975. The Precambrian of Ethiopia and some aspects of the Geology of the Mozambique Belt. Bulletin Geophysics. Obs., Addiss Ababa University, 15: 27-43.

Lydon, J.W. 1988. Volcanogenic massive sulphide deposits. Part 2: Genetic models. Geoscience Canada, 15: 43-65.

Mercier-Langgevin, P., Hannington, M.D., Dube, B \& Becu, V. 2011. The gold content of volcanogenic massive sufide deposits. Mineralium Deposita, 46:509-539.

Mickiale, G. 2014. Geological, petrographical and geochemical study of gold mineralization in May-Hibey, northwestern Tigray, Ethiopia. M.Sc thesis, Department of Earth Science, Mekelle University, Ethiopia. 110p. 
Pearce, J.A. 1980. Geochemical evidence for the genesis of and erupting setting of lavas from Tethyan ophiolites In: A. Panayiotou (ed), Ophiolites. Proceedings of International symposium. Geological Survey Department, Nicosia, Cyprus, pp 261-277.

Peccerillo, A \& Taylor, S.R. 1976. Geochemistry of Eocene calc-alkaline volcanic rocks from the Kastamonu area, northern Turkey. Contributions to Mineralogy and Petrology, 58: 63-81.

Piercey, S.J. 2011. The setting, style and role of magmatism in the formation of volcanogenic massive sulfide deposits. Mineralium Deposita, 46:449-471.

Stern, R. J. 1994. Arc assembly and continental collusion in the Neoproterozoic East African orogen: Implications for the consolidation of Gondwanaland. Annual Review of Earth Science, 22: 319-351.

Tadesse, S., 2000. Genesis of the shear zone related gold vein mineralization of the Lega Dembi gold deposit, Adola gold field, Southern Ethiopia. Gondwana Research, 7(2): 481-488.

Tadesse, S. 2006. Mineral resources potential of Ethiopia, Addis Ababa, 212p.

Tadesse, T., Hoshino, M \& Sawada, Y. 1999. Geochemistry of low-grade metavolcanic rocks from the Pan-African of the Axum area-Northern Ethiopia. Precambrian Research, 99: 101-124.

Teklay, M. 1997. Petrology, Geochemistry, and Geochronology of Neoproterozoic Magmatic Arc Rocks from Eritrea: Implications for Crustal Evolution in the southern Nubian Shield. Memoir, Department of Mines, Eritrea, 1:125.

Teklay, M., Kröner, A., Mezger, K \& Oberhansli, R. 1998. Geochemistry, Pb-Pb single zircon ages and $\mathrm{Nd}-\mathrm{Sr}$ isotope composition of Precambrian rocks from southern and eastern Ethiopia: Implication for crustal evolution in east Africa. Journal African Earth Science, 26: 207-227.

Thornton, C.P \& Tuttle, O.F. 1960. Chemistry of igneous rocks I. Differentiation index. American Journal of Science, 258: 664-684. 